\title{
HUBUNGAN ROMANTIS DI MEDIA SOSIAL (RESEPSI PENGGUNA TERHADAP KETERBUKAAN HUBUNGAN ROMANTIS YANG DIUNGGAH SELEBGRAM DI INSTAGRAM)
}

\author{
Maya Puji Lestari, Rina Sari Kusuma \\ Universitas Muhammadiyah Surakarta \\ Email: mayapuji@gmail.com, Rinasari.kusuma@ums.ac.id
}

\begin{abstract}
ABSTRAK
Melalui analisis resepsi yang Stuart Hall, penelitian ini bertujuan untuk mengetahui resepsi pengguna mengenai keterbukaan hubungan romantis yang ada di instagram. Seluruh informan bergender perempuan dengan latar belakang usia dan profesi yang beragam. Setelah melakukan pengumpulan data melalui metode wawancara dan dokumentasi, didapatkan hasil jika norma agama dan adat budaya membentuk batasan pada postingan-postingan yang ditoleransi untuk disebarkan di instagram. Para informan menyetujui jika pernikahan merupakan cita-cita pada hubungan romantis dan menjadi institusi yang melegalkan segala keterbukaan hubungan romantis di instagram. Realitas di instagram menciptakan nilai dan konsep baru di dunia nyata, salah satunya adalah standarisasi pernikahan yang instagram-able. Di samping itu, sebagian besar informan tidak menyetujui apabila kemesraan diekspresikan secara berlebihan di instagram karena bertentangan dengan norma moral yang berlaku secara kolektif di masyarakat. Perbedaan resepsi terjadi pada informan yang memiliki latar belakang gaya hidup terbuka, postingan kemesraan yang diunggah di instagram ditoleransi selama pihak berwenang belum melakukan tindakan terkait postingan yang dianggap meresahkan di dunia maya.
\end{abstract}

Kata Kunci: Analisis resepsi, hubungan romantis, cinta, instagram, selebgram.

\begin{abstract}
Using Stuart Hall's reception analysis, this study aims to know the user's reception of romantic relationship that discloses in instagram. All informants are female with various age and profession background. After data collection through interview and documentation method, obtained the result that the norm of religion and culture are forming restriction of instagram posts that is tolerable to share. Informants agreed that marriage is such an ideal of romantic relationship and become an institutions that legalized all the romantic relationship disclosure in instagram. Instagram creates a new idea and value that can be adopted in the real world, one of which is standardization of instagramable wedding celebration. Moreover, some of informant did not approve that intimate which involve physical contact express in instagram because contrary to the collective norms. But, the difference receptions occur on an informant who has open lifestyle, intimate posts in instagram are tolerable as long as the authorities have yet to take any action related to post that considered as disturbing content in cyber world.
\end{abstract}

Keywords: Reception Analysis, romantic relationship, love, instagram, selebgram

\section{A. PENDAHULUAN}

Media sosial awalnya hadir untuk memenuhi kebutuhan komunikasi guna memelihara kualitas hubungan yang berjarak. Media ini memungkinkan siapa saja bisa terhubung tanpa mengenal batasan ruang dan waktu. Dengan keunggulan tersebut, tidak heran apabila masyarakat 
berbondong-bondong menggunakan media sosial di perangkat ponsel pintarnya. Pengguna bebas memilih platform dan konten apa saja yang ingin mereka konsumsi, serta bebas memilih konten apa saja yang akan diposting di akun media sosial mereka. Pada akhirnya, media sosial tidak sekadar berfungsi sebagai media berinteraksi, tetapi juga dimanfaatkan pengguna sebagai arena unjuk diri.

Salah satu platform media sosial yang populer di Indonesia adalah instagram. Berdasarkan data dari Asosiasi Penyelenggara Jaringan Internet Indonesia (APJII) yang melakukan riset di tahun 2016, instagram digunakan oleh 19,9 juta orang di Indonesia. Media sosial ini memungkinkan penggunanya untuk mengunggah foto maupun video dengan durasi maksimal 60 detik. Pengguna dibebaskan untuk menulis keterangan foto (caption) apapun mengenai foto/video yang mereka unggah. Di pertengahan 2017, instagram meluncurkan fitur 'live'. Dengan adanya fitur ini pengguna bisa meliput aktivitasnya secara langsung dan dikonsumsi tidak hanya oleh followersnya, tetapi juga oleh seluruh pengguna secara global.

Websta.me, sebuah website analisa instagram, menyebutkan pada tanggal 8 Juli 2017, tagar \#love digunakan pada $1,106,527,954$ postingan dan menduduki peringkat teratas sebagai tagar yang banyak digunakan oleh pengguna instagram. Hal ini mengindikasikan bahwa postingan yang bertemakan cinta cenderung diminati oleh banyak orang. Oleh karena itu, kontenkonten yang menunjukkan keterbukaan dalam mengekspresikan cinta atau hubungan romantis bisa sangat dekat dan banyak digemari. Gambar 1 menunjukkan postingan-postingan dengan tagar \#love.

Sebuah postingan di instagram dapat dikatakan menarik apabila memperoleh banyak 'likes' dan komentar yang kemudian menghantarkan para likers dan komentator ini menjadi followers. Dari fenomena tersebut, kemudian muncul istilah 'selebgram' yang merujuk pada suatu akun dengan konten yang memiliki banyak likes dan mendulang banyak followers. Selebgram ini kemudian memiliki power terhadap followers-nya karena memiliki daya tarik juga kemampuan dalam mengelola konten di akun instagramnya.

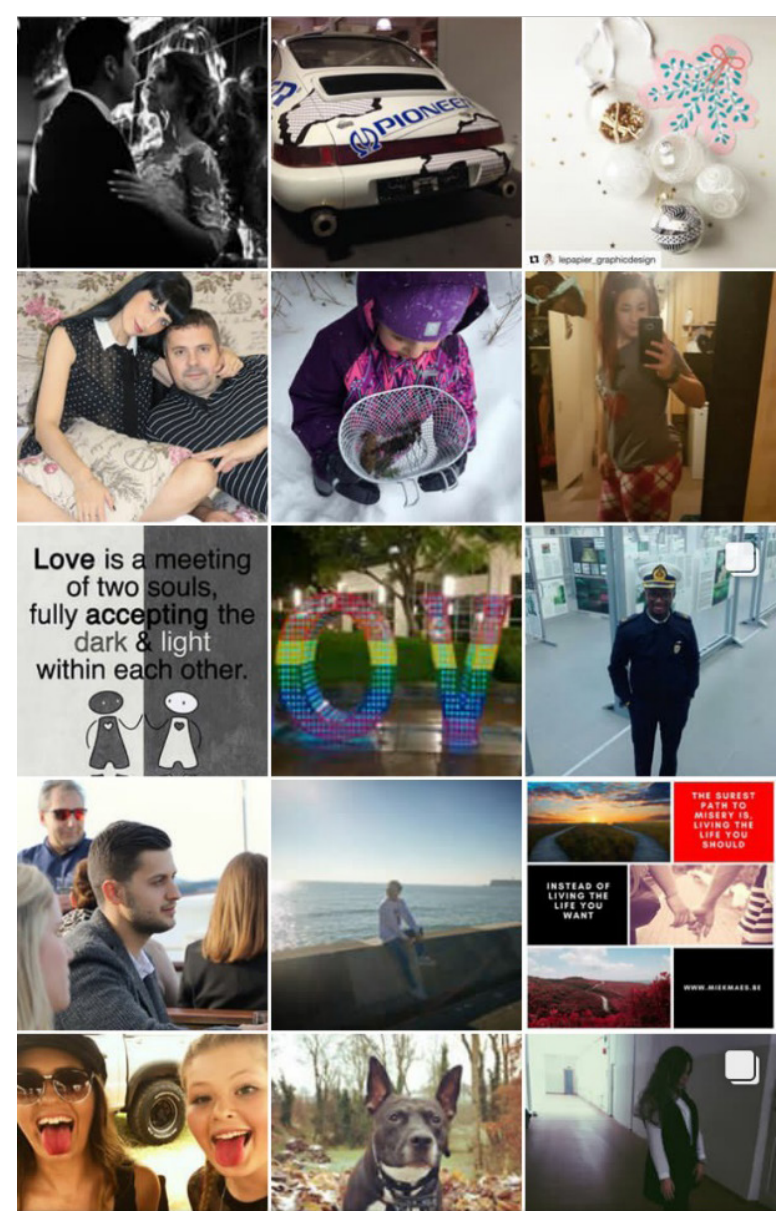

Gambar 1. Postingan instagram bertagar \#love

Penelitian yang dilakukan oleh Kara Chan (2011) di Taiwan menjadi referensi peneliti untuk melihat bagaimana peran tokoh terkenal atau selebriti membentuk suatu konsep di benak remaja. Kara Chan meneliti konsep gender yang remaja perempuan dapatkan dari selebritis. Hasil dari penelitian ini adalah selebriti menjadi tokoh utama pembentuk pemahaman pada remaja mengenai perilaku apa saja yang seharusnya perempuan lakukan dan tidak lakukan.

Terkait hubungan romantis, terdapat studi yang mencari bagaimana resepsi audiens terhadap konsep hubungan cinta yang didapat dari konsumsi media massa. 
Penelitian ini dilakukan oleh Aran-Ramspott, dkk. (2015) pada mahasiswa antar jurusan yang menonton drama seri percintaan di Spanyol. Penelitian ini mendapatkan hasil jika perbedaan resepsi terhadap teks media didasarkan pada dua variabel, antara lain gender dan komparasi realitas media dengan realitas sosial para responden. Responden perempuan menolak representasi peran gender pada drama seri tersebut, yaitu laki-laki digambarkan lebih dominan dibandingkan perempuan dalam hubungan romantis.

Berdasarkan latar belakang di atas, peneliti tertarik untuk melihat bagaimana resepsi khalayak, dalam hal ini disebut sebagai pengguna instagram, terhadap keterbukaan hubungan romantis yang dilakukan oleh selebgram. Untuk menjawabnya, penelitian ini mengadaptasi analisis resepsi dari Stuart Hall yang akan menggali penerimaan berdasarkan dua kategori, yakni beda usia dan profesi.

\section{B. TELAAH PUSTAKA}

\section{Social Network Sites}

Boyd dan Ellison (2008) mendefinisikan Social Network Sites (SNS) sebagai layanan berbasis web yang memungkinkan penggunanya untuk membangun profil yang bersifat publik atau semi publik dalam sebuah sistem tertentu, membuat daftar pengguna yang membuka akses keterhubungan, dan berinteraksi dengan pengguna yang ada dalam daftar tersebut.

Pada praktik sehari-hari, SNS lebih populer dengan sebutan media sosial. Safko dan Brake (2009) mendefinisikan media sosial sebagai aktivitas, praktik, perilaku antar pengguna yang tergabung dalam jaringan online untuk berbagi informasi, pengetahuan dan pendapat dalam media yang memungkinkan adanya percakapan.

$\mathrm{Di}$ Indonesia, pengguna internet dan SNS bertumbuh sangat cepat dari waktu ke waktu. Berdasarkan survey yang dilakukan oleh Asosiasi Penyelenggara Jaringan Internet Indonesia (APJII) pada 2016, pengguna internet Indonesia telah mencapai $50 \%$ dari total populasi penduduk. Masih dalam survei yang sama, SNS disebut sebagai media yang sering diakses oleh pengguna. Facebook merajai platform media sosial yang paling sering digunakan, yaitu sebanyak 71,6 juta pengguna, menyusul Instagram 19,9 juta pengguna dan Youtube dengan 14,5 juta pengguna. Dari data ini, dapat dilihat bahwa SNS telah menjadi pilihan media yang paling favorit dipilih pengguna internet di Indonesia.

Salah satu platform SNS yang banyak digunakan di Indonesia, instagram, didirikan pada 2010 lalu dan semakin meningkat popularitasnya sejak 2012. Sebagai SNS yang mengunggulkan konten fotografi dan video, instagram merupakan platform yang menciptakan engagement secara signifikan dan terukur (Lella dalam Budge, 2017). Instagram didefinisikan sebagai aplikasi berbasis visual yang menjadikan teks sebagai konten opsional dan apabila digunakan, teks berfungsi sebagai deskripsi atau penjelas konteks konten utama, yaitu foto atau video (Budge, 2017). Menurut Jose van Dijck (2008), individu mengartikulasikan identitas dirinya sebagai makhluk sosial tidak hanya melalui foto untuk mengambil dan menyimpannya sebagai dokumen pribadi tetapi juga dengan ikut serta dalam pertukaran foto secara komunal untuk menandai dirinya sebagai konsumen dan produsen budaya interaktif. Instagram merupakan platform yang memungkinkan budaya interaktif tersebut terjadi dan dikembangkan.

Instagram juga turut memberikan pengaruh pada hubungan interpersonal. Penelitian yang dilakukan oleh Sa'adatina (2017) menjelaskan bahwa instagram dapat difungsikan sebagai fasilitator dalam mengembangkan hubungan di masa penjajakan, presentasi diri di instagram disebutkan mempengaruhi penilaian sebagai pasangan yang potensial, instagram dapat dijadikan sebagai tanda komitmen dalam hubungan berpacaran melalui publikasi foto maupun video, keterbukaan pada pasangan tercermin pada pertukaran kata sandi akun media sosial, foto, tombol suka, following dan follower 
diinterpretasikan sebagai pesan nonverbal dari bentuk tindakan dan interaksi dengan tafsiran tertentu, instagram dijadikan media penunjukkan emosi terhadap pasangan.

Alkandari, dkk. (2016) menyebutkan beberapa motif menggunakan instagram, antara lain sebagai ekspresi diri, interaksi sosial, pembentuk opini, ruang eksperimen dan pemenuhan hiburan. Kebutuhan untuk mengekspresikan diri dan berinteraksi merupakan alasan terkuat mengapa seseorang membuka dirinya secara virtual melalui instagram.

\section{Keterbukaan Diri Secara Virtual}

Keterbukaan diri didefinisikan sebagai proses pengungkapan informasi diri kepada orang lain (West dan Turner, 2010). Keterbukaan diri merujuk pada perilaku komunikasi seseorang yang dilakukan secara sengaja untuk membuat orang lain mengetahui tentang dirinya (Derlega dan Berg dalam Tsay-vogel, dkk., 2016). Definisi lain menyebutkan jika keterbukaan diri adalah komunikasi verbal kepada orang lain mengenai informasi personal (Coxby dalam Omarzu, 2000). Dalam hal ini, informasi personal mencakup fakta-fakta mengenai diri, pendapat dan sikap yang diyakini atau informasi mengenai emosi dan perasaaan yang dimiliki.

Terkait keterbukaan diri secara virtual, khususnya melalui social network site (SNS), Nguyen, dkk. (2012) mengemukakan bahwa SNS menawarkan banyak fitur yang mampu meningkatkan keterbukaan diri di antara para penggunanya. Pada media sosial instagram, fitur-fitur tersebut antara lain berupa foto, video, caption, instagram-story dan instagram live.

Peneliti lain juga menyebutkan jika seseorang harus mengemukakan informasi personalnya untuk mendapatkan benefit dari penggunaan media sosial atau SNS-nya (Vitak dalam Masur dan Scharkow, 2016). Di samping itu, sejumlah peneliti berpendapat jika keterbukaan diri tidak hanya membantu untuk menginisiasi interaksi sosial, tetapi juga memfasilitasi kontak sosial dan pertemanan dalam jangka panjang (Nosko, dkk., 2010).

Penelitian ini mengambil fenomena keterbukaan diri secara virtual yang dilakukan oleh public figure di instagram atau dikenal dengan sebutan selebgram. Para pemilik akun dengan followers lebih dari 10.000 akun ini membagikan cerita kehidupan pribadinya kepada publik. Keterbukaan tersebut diperlihatkan melalui foto dan/atau video berkualitas yang menarik untuk disaksikan. Kemudian, narasi mengenai foto dan/atau video dikisahkan melalui caption yang tertera di bawah postingan. Di samping itu, para selebgram juga dapat mengkreasikan tampilan feed instagramnya. Feed adalah sebutan untuk tampilan muka profil instagram yang terdiri atas: avatar, bio dan deretan postingan visual yang telah diunggah. Pada beberapa akun selebgram, feed dibuat dengan komposisi warna yang konsisten diterapkan sehingga audiens yang melihatnya dapat menangkap mood and feel yang coba ditampilkan oleh pemilik akun.

Derlega dan Grzelak (Omarzu, 2000) mengemukakan gagasan mengenai fungsi dari keterbukaan diri. Mereka menyatakan bahwa seseorang membuka dirinya adalah untuk mencapai beberapa tujuan, antara lain: ekspresi, pengembangan relasi, klarifikasi diri, validasi sosial, dan kontrol sosial. Selain itu, keterbukaan diri juga dilakukan secara strategis. Artinya, seseorang akan menyeleksi dan memilah informasi apa saja yang akan mereka ungkapkan bergantung pada seberapa besar keterbukaan diri tersebut akan menunjang pencapaian misinya (Quattrone dan Jones dalam Omarzu, 2000).

Collins dan Miler (Rains, dkk., 2014) mengatakan bahwa ada asosiasi positif antara keterbukaan diri dan respon penerima. Semakin banyak keterbukaan diri yang ditampilkan, semakin diminati dan disukai oleh banyak orang.

\section{Hubungan Romantis}

Hubungan romantis merupakan hasil dari pengembangan relasi interpersonal. Altman dan Taylor (West dan Turner, 
2010) memperkenalkan teori penetrasi sosial sebagai teori yang mengantarkan pengembangan relasi interpersonal. Teori ini merujuk pada proses yang membawa relasi umum kepada relasi yang bersifat lebih intim. Prosesnya dimulai dari orientasi, yakni pengungkapan informasi yang bersifat umum. Apabila kedua belah pihak merasa diuntungkan, mereka selanjutnya masuk pada proses yang kedua, yaitu pertukaran afektif eksploratif. Pada tahap ini, masingmasing pihak menggali informasi secara lebih detil. Ketika muncul dorongan untuk mengkritik dan mengevaluasi, artinya mereka telah masuk ke dalam proses yang ketiga, yaitu pertukaran afeksi. Proses tertinggi dari pengembangan relasi interpersonal ini adalah proses pertukaran yang seimbang, yakni kedekatan yang memungkinkan untuk saling memperkirakan tindakan dan memberikan respon yang baik (Altman dan Taylor dalam Littlejohn, 2009). Pada hubungan yang melibatkan afeksi, di proses terakhir inilah hubungan romantis terbentuk.

Rasa cinta dapat terjalin pada relasi keluarga, sahabat atau pasangan. Pada relasi keluarga atau sahabat, rasa cinta bersifat lebih kasual, sedangkan pada pasangan, cinta bersifat lebih kompleks dengan melibatkan rasa romantisme yang lebih kuat (Miller, 2012). Oleh sebab itu, penelitian ini menggunakan terminologi hubungan romantis untuk menggambarkan relasi cinta dengan pasangan

Furman, dkk. (1999) menjelaskan tiga definisi hubungan romantis berdasarkan beberapa karakteristik, yaitu keromantisan yang ada pada suatu hubungan dan menjadi pola yang berlangsung terus menerus dari interaksi dua individu yang masingmasing mengakui terikat dalam hubungan. Kedua, terdapat unsur kesukarelaan dari kedua individu untuk mempertahankan hubungan romantis mereka. Ketiga, hubungan romantis merupakan bentuk dari ketertarikan (attraction).

Stenberg mengenalkan Teori Segitiga Cinta (Miller 2012), antara lain keintiman, gairah dan komitmen. Aran-Ramspott, dkk.
(2015) mendefinisikan ketiga komponen teori tersebut, keintiman diartikan sebagai representasi dari rasa kedekatan dan keterkaitan. Konsep ini diwujudkan lewat perasaan senang ketika bersama, rasa menghargai satu sama lain serta saling memberi dan menerima dukungan moril. Gairah merupakan keinginan terikat dengan pasangan, antara lain lewat kontak fisik dan hasrat seksual. Sedangkan, komitmen adalah keputusan untuk terlibat dalam hubungan serius dan usaha-usaha untuk mempertahankan hubungan.

Berdasarkan teori tersebut, Miller (2012) mengelompokkan 4 tipe hubungan yang melibatkan afeksi, antara lain: romantic love, yaitu ketika terdapat keintiman dan gairah. Companionate love, ketika keintiman dan komitmen membentuk hubungan yang lebih dekat. Fatous love, ketika gairah dan komitmen menimbulkan tindakan di luar akal dan consummate love, yaitu ketika keintiman, gairah dan komitmen menciptakan hubungan yang sempurna. Pada tipe consummate love inilah hubungan dilihat sebagai hubungan yang ideal dan dicita-citakan.

Eckstein dan Morrison (1999) berpendapat bahwa pengungkapan rasa dalam hubungan romantis dapat meningkatkan rasa empati satu sama lain. Sementara itu, Gary Chapman (Chapman, 1995 dalam Eckstein dan Morrison, 1999) memperkenalkan lima ekspresi dalam hubungan romantis, antara lain: pernyataan cinta, meluangkan waktu bersama, memberikan hadiah, sentuhan fisik dan melakukan hal yang disukai oleh pasangan.

\section{Analisis Resepsi}

Konsep dasar pada analisis resepsi adalah menempatkan audiens, sebagai penerima teks media, bersifat aktif dan memiliki daya untuk membentuk penerimaan serta persepsi mengenai diskursus media. Analisis resepsi fokus pada cara audiens mengkontruksi makna dari media (Littlejohn, dkk., 2009).

Frank Biocca (Mc.Quail, 2000) menyebutkan lima tipe audiens aktif, 
pertama, selektifitas yaitu audiens dianggap selektif ketika memilih dan mengonsumsi media. Ada pertimbanganyang dibuatketika memutuskan mengonsumsi media tertentu. Kedua, utilitarianisme, yakni audiens yang aktif mengonsumsi media untuk mencapai tujuan dan memenuhi kebutuhan tertentu. Ketiga, intensionalitas, tipe audiens yang aktif mengonsumsi media atas kesengajaan. Audiens telah memiliki kepentingan tertentu ketika memutuskan untuk mengonsumsi sebuah media. Keempat, keikutsertaan, yaitu audiens yang aktif berpikir tentang alasan dalam mengonsumsi media dan impervious to Influence, tipe audiens yang tidak mudah terpengaruh oleh dan resisten terhadap bujukan teks yang diproduksi media.

Teks media memiliki makna yang rapuh dan tidak bisa ditetapkan oleh komunikator karena makna yang diproduksi dapat diinterpretasikan ke dalam berbagai cara (Nanda, 2012). Analisis resepsi merupakan studiyang mendalam terhadap proses aktual melalui wacana dalam media diasimilasikan ke dalam wacana dan praktik-praktik budaya khalayak (Aryani, 2008). Stuart Hall mengenalkan konsep encoding-decoding dalam mengkaji hubungan audiens dengan media. Encoding adalah proses media memproduksi teks, sedangkan decoding merupakan proses penerimaan teks media oleh audiens berdasarkan persepsi, pemikiran dan pengalaman mereka (West dan Turner, 2010).

Hall memaparkan bagaimana decoding bekerja. la mengkategorikan audiens berdasarkan tiga posisi, yaitu dominanthegemonic, negotiated dan oppositional. Dominant-hegemonic merupakan posisi audiens yang menerima dan memaknai teks media secara penuh. Apa yang disampaikan oleh produsen teks dimaknai secara persis oleh audiens. Negotiated adalah posisi audiens yang memaknai teks media secara situasional. Mereka menerima ideologi teks namun memaknainya dengan logika dan membedakan makna yang dipeoleh dengan makna yang diproduksi. Sedangkan, oppositional adalah audiens yang memahami makna tersirat dari teks media namun memiliki pemaknaan yang bertolak-belakang. Hall menyatakan bahwa perbedaan status sosial, atau bisa disebut sebagai perbedaan kelas, turut membentuk posisi penerimaan audiens ini (Shaw, 2017). Morley (Nanda, 2012), menyebutkan jika nilai kultural dan pengalaman yang dimiliki merupakan faktor penting bagi audiens untuk mengurai pesan. Oleh sebab itu, pada teks media yang sama, audiens akan menginterpretasikan pesan tersebut secara berbeda dan mengaitkannya dengan identitas sosial yang dimilikinya.

Ada tiga faktor yang dapat terlihat pada proses encoding-decoding di kajian analisis resepsi, antara lain media, teks dan audiens. Media merupakan produsen yang membuat atau menciptakan teks berupa kodekode yang mengandung makna tertentu untuk ditransfer kepada audiens selaku penerima dan konsumen teks. Mathieu (2015) mengungkapkan jika analisis resepsi adalah metodologi yang dulunya dirancang untuk mengetahui implikasi simbolik, yaitu pembentukan makna, melalui media massa, khususnya televisi.

Manovich (Picone, 2017) memakai sebutan 'user' atau dalam Bahasa Indonesia diartikan sebagai 'pengguna' untuk menyebut orang-orang yang berinteraksi dengan media baru. Picone (2017) kemudian menggunakan kata 'media user' atau 'pengguna media' untuk menyebut penerima teks pada media sosial. la menjabarkan tiga konsep mengenai pengguna media. Pertama, medium-agnostic, tidak ada konsep yang mendefinisikan hubungan antara pengguna dengan jenis media atau penggunaan media.. Kedua, scalable, pengguna media bersifat individual, berkebalikan dengan 'audiens' yang menurut Livingstone (Picone, 2017) menyiratkan makna kelompok. Ketiga, non-linear, menempatkan pengguna media lebih dari sekadar penerima konten.

Penelitian yang dilakukan oleh Kandi Aryani (2008) di Surabaya merupakan referensi penelitian ini. Penelitian yang berjudul 'Analisis Penerimaan Remaja terhadap Wacana Pornografi Dalam Situssitus Seks Di Media Online' ini bertujuan untuk melihat bagaimana pemaknaan, sikap 
dan perilaku remaja terhadap pornografi yang ada di media online. Penelitian ini mendapatkan hasil jika para informan setuju pornografi merupakan hal yang tabu dan bertentangan dengan norma yang menjadi konsensus sosial masyarakat. Di sisi lain, mereka memiliki pandangan situs-situs tersebut dianggap sebagai hal yang tidak bisa dihindari dan dilarang sehingga mereka memilih untuk menoleransi keberadaannya.

\section{METODE}

Penelitian ini menggunakan pendekatan kualitatif deskriptif yang bertujuan untuk menguraikan fenomena secara sistematis dan apa adanya. Pendekatan kualitatif lebih menekankan pada kedalaman (depth) daripada keluasan (breadth) (Kriyantono, 2006).

Populasi pada penelitian ini merupakan perempuan yang aktif menggunakan instagram dan mem-follow minimal satu selebgram ber-followers lebih dari 10.000 yang rutin mengunggah postingan yang menunjukkan keterbukaan mengenai hubungan romantisnya. Oleh karena itu, teknik purposive sampling digunakan untuk mendapatkan sampel yang representatif.

Sampel pada penelitian ini berjumlah 6 orang dengan kriteria berikut: Kategori usia 17-20 tahun, 22-25 tahun dan 27-30 tahun. Kategori profesi Mahasiswa, Karyawan dan Ibu Rumah Tangga. Kategori usia tersebut dipilih karena pada usia muda, individu cenderung lebih mudah merangkul, berinteraksi dan beradaptasi secara cepat dengan teknologi baru (Kusuma, 2016). Usia dan profesi dibedakan atas asumsi adanya perbedaan pengalaman yang akan memengaruhi penerimaan dan interpretasi terhadap konten media yang dikonsumsi. Detil profil informan disajikan pada Tabel 1 di bawah ini.

Tabel 1. Profil Informan

\begin{tabular}{llll}
\hline Responden & \multicolumn{1}{c}{ Usia } & \multicolumn{1}{c}{ Profesi } & \multicolumn{1}{c}{ Domisili } \\
\hline Informan 1 & 24 tahun & Mahasiswa Pascasarjana & Yogyakarta \\
informan 2 & 24 tahun & Karyawan Swasta & Jakarta \\
informan 3 & 28 tahun & Ibu Rumah Tangga & Solo \\
Informan 4 & 26 tahun & Karyawan Swasta & Bogor \\
Informan 5 & 19 tahun & Mahasiswa & Bogor \\
informan 6 & 20 tahun & Mahasiswa & Yogyakarta \\
\hline
\end{tabular}

Data dikumpulkan lewat dokumentasi dan wawancara. Mulanya, responden diminta untuk mengumpulkan 10 konten yang diunggah selebgram di instagram. Ketentuannya adalah 5 konten merupakan keterbukaan hubungan romantis yang mereka setujui dan 5 konten lainnya merupakan keterbukaan hubungan romantis yang tidak mereka setujui. Responden dibebaskan untuk mengambil konten dari akun selebgram manapun, namun akun tersebut harus memiliki followers lebih dari 10.000 dan merupakan akun yang telah lebih dari 6 bulan mereka ikuti. Ketentuan tersebut didasarkan pada asumsi semakin banyak followers maka semakin banyak postingan keterbukaan yang diunggah oleh suatu akun. Sedangkan, lama waktu following menandakan banyaknya waktu terpaan yang dialami oleh responden terhadap postingan akun selebgram tersebut. Hasil dari dokumentasi ini nantinya akan menjadi pembanding dengan data yang diperoleh dari proses wawancara.

Analisa data dilakukan dengan teknik yang diperkenalkan oleh Miles dan Hubermen (Nanda 2012), yaitu: reduksi data, penyajian data dan gambaran kesimpulan atau verifikasi. Reduksi data merupakan proses seleksi dan penyederhanaan data yang diperoleh dari lapangan. Proses selanjutnya adalah menerjemahkan kodekode yang terdapat dalam data. Tahap selanjutnya ialah penyajian data, yaitu 
mengelompokkan data-data dan dikaitkan sesuai dengan teori yang digunakan. Tujuannya agar data dapat lebih mudah dipahami sehingga peneliti dapat mengambil simpulan penelitian. Tahap terakhir adalah gambaran kesimpulan atau verifikasi. Pada tahap ini, peneliti pada dasarnya mengimplementasikan prinsip induktif dengan mempertimbangkan polapola data yang ada dan atau kecenderungan dari display data yang telah dibuat (Rachman, 2012).

Untuk menguji validitas data, peneliti menggunakan member check, yaitu melakukan cek data kepada responden. Hal ini dilakukan untuk mengetahui kesesuaian antara data yang diperoleh dan dianalisis dengan informasi yang diberikan oleh responden.

\section{HASIL DAN PEMBAHASAN}

Peneliti menemukan data apabila seluruh selebgram yang di-follow oleh informan bergender perempuan, memiliki followers lebih dari 10.000, heteroseksual dan berdomisili di Jakarta. Lewat instagramnya, selebgram tidak hanya membagikan postingan hubungan romantis, tetapi juga postingan lain, seperti: aktualisasi melalui postingan mengenai diri, relasi interpersonal melalui postingan bersama keluarga dan teman, serta endorsement melalui foto bersama produk berbayar. Postingan tidak hanya dibagi melalui feed, sebutan tampilan muka ketika membuka profil suatu akun instagram, tetapi juga pada instagram-story dan live, fitur instagram yang memfasilitasi pengguna mengunggah foto/video yang hanya bertahan 24 jam.

Berdasarkan tiga posisi audiens yang dikemukakan Hall tersebut, penelitian ini menghasilkan tiga macam kategori, antara lain: agama dan adat budaya membentuk batasan pada hubungan romantis yang disebar di instagram; pernikahan sebagai cita-cita pada hubungan romantis dan kemesraan yang ditampilkan di instagram.

\section{Agama dan Adat Budaya Membentuk Batasan pada Hubungan Romantis yang Disebarkan di Instagram}

Ada dua jenis hubungan romantis yang para informan saksikan di instagram, antara lain hubungan romantis pada pasangan pacaran dan hubungan romantis pada pasangan menikah. Tidak hanya melalui foto atau video, ekspresi hubungan romantis juga diungkapkan melalui caption yang terlampir pada setiap postingan.

"Postingan hubungan romantis itu semacam pesan bahwa mereka benar saling mencintai. Kalau pasangan yang udah menikah, postingan seperti itu kayak berusaha menampilkan bahwa mereka masih romantis dan kehidupannya bahagia," (Informan 1, 24 tahun, mahasiswa pascasarjana)

Stenberg mendefinisikan hubungan cinta sebagai sekumpulan perasaan, pemikiran dan keinginan yang ketika dialami bersama, dapat diinterpretasikan sebagai cinta. (Aran-Ramspott, dkk., 2015). Dalam teorinya yang dikenal sebagai Teori Segitiga Cinta, Stenberg mengemukakan tiga faktor yang melandasi hubungan romantis, antara lain keintiman, gairah atau kemesraan dan komitmen (Miller 2012). Agama dan adat budaya merupakan dua aspek yang melatarbelakangi para informan meresepsi postingan-postingan yang mencirikan hubungan romantis tersebut.

Dalam kehidupan sosialnya, manusia bersikap dan berperilaku sesuai dengan norma-norma yang diakui dan diterima secara kolektif di lingkungannya. Norma tersebut berisi perintah atau larangan agar manusia dapat berperilaku sesuai dengan kaidah-kaidah sehingga tercipta ketertiban serta kesinambungan dalam kehidupan bersama di masyarakat (Nurseno dalam Pratama, 2011). Agama dan budaya adalah dua hal yang befungsi sebagai pembentuk norma-norma. Dua hal tersebut memiliki tata cara dan peraturan sendiri dalam menjaga tatanan hidup masyarakatnya (Asmara, 2016). Berdasarkan keterangan para informan, agama dan adat budaya merupakan halhal yang mendasari terbentuknya batasan- 
batasan apa yang patut dan tidak patut dilakukan di ranah publik.
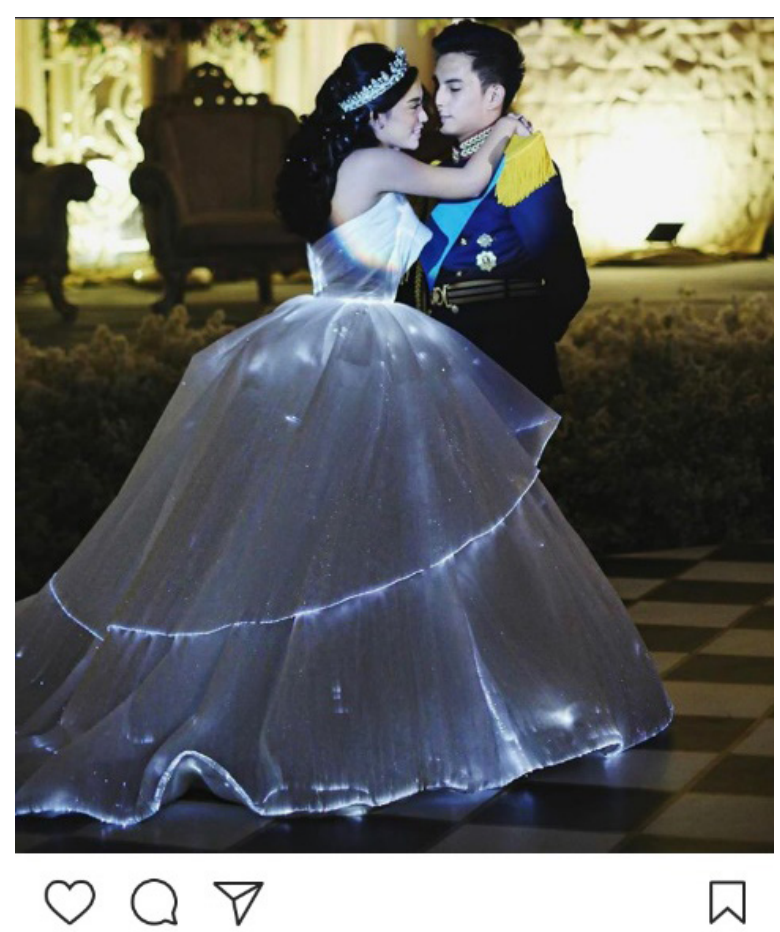

ఐ

Liked by liskawidia, saturdaylabel and 214,307 others

rachelvennya Thankyou for letting my dream come true Mas

\#nikorachelwedding

View all 5318 comments

\section{Gambar 2. Postingan selebgram terkait hubungan romantis}

Media sosial merupakan medium yang memfasilitasi penggunanya untuk saling berinteraksi dan membangun hubungan sosial. Sebagian akademisi menilai bahwa media sosial adalah gambaran apa yang terjadi di dunia nyata sehingga nilai-nilai yang ada di masyarakat maupun komunitas bisa muncul di sana (Nasrullah, 2015). Hal ini sesuai dengan apa yang dilakukan oleh para informan, yakni memanifestasikan nilai dan norma yang berlaku di kehidupan nyatanya ke dalam dunia virtual, yaitu media sosial. Beberapa postingan hubungan romantis dinegosiasi oleh para informan, yaitu pada postingan yang memenuhi batasanbatasan norma sesuai dengan agama dan adat budaya yang dianutnya. Gambar 2 merupakan contoh postingan hubungan romantis yang diekpresikan oleh selebgram melalui instagram.
"Aku sih gak masalah dengan hubungan romantis kayak gimana yang mereka (selebgram) lakukan di ranah privat. Tapi, ketika itu dipublikasikan lewat media sosial, harusnya jangan berlebihan dan jangan diposting secara terus menerus karena kalau dilihat dari agama dan norma rasanya gak patut dilihat banyak orang, apalagi mereka itu followersnya banyak," (Informan 1, 24 tahun, mahasiswa pascasarjana).

Informan 1 berasal dari kota kecil di Jawa Timur yang dibesarkan di lingkungan keluarga muslim yang moderat. la merasa perlu adanya pembedaan antara hubungan romantis dalam lingkup privat dan hubungan romantis yang diekspresikan ke khalayak ramai melalui media sosial. Menurutnya, postingan yang dianggap berlebihan adalah postingan yang terlalu menonjolkan kemesraan, kemewahan dengan bertukar hadiah-hadiah mewah dan diperlihatkan dalam frekuensi waktu yang terus-menerus.

Norma agama dan adat budaya mengatur apa yang patut disebarkan ke publik dan mana yang tidak. Agama berfungsi sebagai sistem sosial yang dibuat oleh penganut-penganutnya yang berporos pada kekuatan-kekuatan non-empiris yang dipercayainya dan didayagunakannya untuk mencapai keselamatan bagi diri mereka dan masyarakat luas pada umumnya (Hendropuspito dalam Pratama, 2011). Sedangkan, adat budaya adalah sistem pengetahuan yang digunakan oleh sekelompok besar orang yang dapat bersifat individualistik maupun kolektif (Ruben dan Stwart, 2013). Ketika suatu sistem tersebut disepakati dan diterapkan, saat itulah budaya tersebut diterima.

Pada budaya yang bersifat kolektif, kesepakatan mengenai norma-norma menekankan pada tujuan kelompok, tanggung jawab bersama, harmoni dan kerja sama kelompok (Ruben dan Stwart, 2013). Hal inilah yang membuat norma antara kelompok budaya satu dan lainnya dapat beragam. Informan 2 yang berdomisili di Jakarta menganggap kemewahan pada 
ekspresi hubungan romantis adalah sesuatu yang wajar.

"It's ok lah kalau kasih kado mahal ke pacar terus di-upload di instagram karena mereka punya kemampuan buat ngasih itu. Kalau misal gue di posisi mereka juga pasti seneng ngasih dan posting kayak gitu deh," (Informan 2, 24 tahun, karyawan swasta).

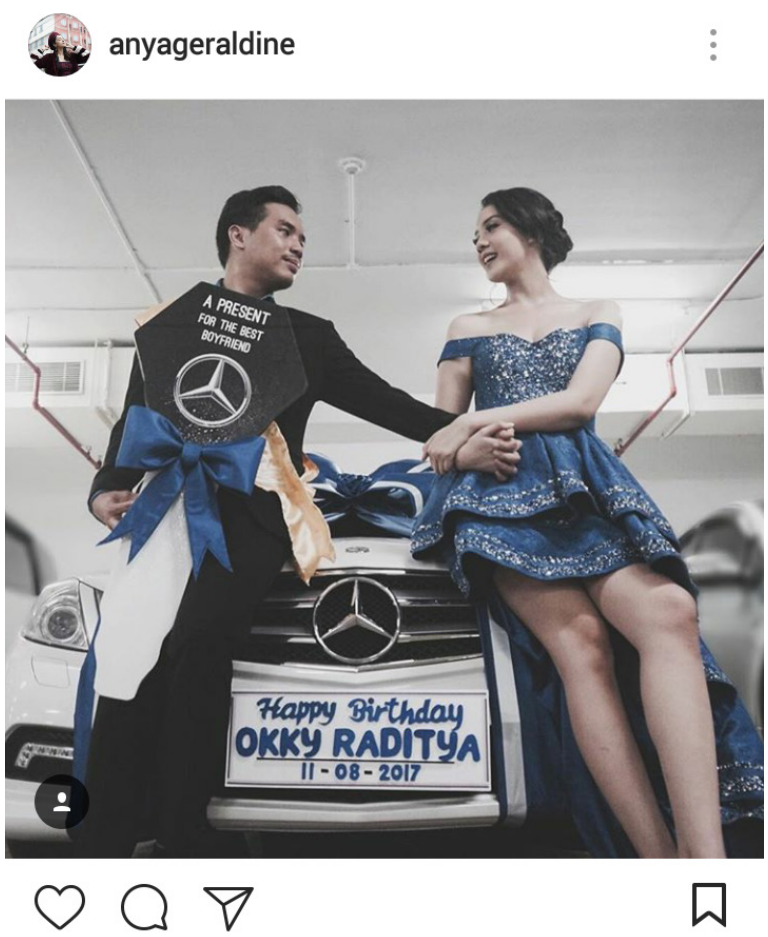

Liked by nurmahapsari and 105,393 others

anyageraldine a present for the best boyfriend

Gambar 3. Pemberian hadiah mewah dalam hubungan romantis

Ada banyak cara untuk mengekspresikan rasa cinta terhadap pasangan, salah satunya adalah memberi hadiah. Pemberian hadiah merupakan representasi fisik dari rasa cinta yang bersifat abstrak dan tidak terlihat (Chapman dalam Eickstein dan Morristen, 1999). Selebgram mewujudkannya dengan memberi hadiah mewah kepada pasangan seperti barang-barang bermerk, motor sport hingga mobil mahal. Sebagian informan menganggap postingan tersebut berlebihan, namun bagi Informan 2 yang terbiasa menggunakan barang-barang mewah hal tersebut dapat ditoleransi. Postingan yang mengekspresikan hubungan romantis melalui berbagi hadiah mewah dapat dilihat di gambar 3 di bawah ini.Sementara itu, Informan 6 menegosiasi postingan hubungan romantis yang menunjukkan kemesraan karena menurutnya terdapat perbedaan norma dan kebiasaan antara dirinya yang berada di kota kecil dan selebgram yang hidup di kota metropolitan.

"Foto-foto rangkul-rangkulan sampai pangku-pangkuan yang di-upload selebgram mungkin aku yang ada di Jogja ngeliat itu masih aneh, cuma kalau di Jakarta kayaknya udah biasa deh. Kalau yang di Jakarta tuh mengacunya udah keluar (negeri) jadi sedikit banyak kepengaruh ke apa yang mereka upload," (Informan 6, 20 tahun, mahasiswa).

Teori Segitiga Cinta Stenberg menjelaskan bahwa salah satu komponen dalam hubungan romantis adalah gairah yang direpresentasikan lewatkemesraan dan kontak fisik. Komponen ini mencerminkan keinginan untuk terikat dengan pasangan (Aran-ramspott, 2017). Kemesraan, kontak fisik hingga aktivitas seksual masih menjadi hal yang tabu untuk diperbincangkan dan diperlihatkan di Indonesia, khususnya pada kota-kota kecil yang mengutamakan adat kesantunan. Namun, melalui media sosial, apa yang menjadi biasa di kota besar diperlihatkan dan menyebar ke daerahdaerah lainnya, termasuk ke daerah domisili Informan 6.

Informan 6 merupakan mahasiswa di Yogyakarta yang berasal dari kota santri, Ponorogo, Jawa Timur. Dididik dalam lingkungan keluarga muslim yang masih menjunjung tinggi adat Jawa membuatnya berpegang teguh pada unggah-ungguh dalam kehidupan sehari-hari. Meski sudah masuk ke tahun kedua di perantauan, ia masih berusaha beradaptasi dengan perbedaan budaya yang kini dihadapinya. Berbeda dengan kehidupan di kota kecil yang masih menerapkan tatanan sosial yang tradisional, kehidupan kota besar yang ditempati oleh masyarakat modern memiliki sistem stratifikasi sosial yang terbuka, nilainilai yang rasional dan sekuler (Syah, 2004). 
Ketika individu menghadapi perubahan budaya akibat bermigrasi dari satu kota ke kota lain, ia akan mengalami proses adaptasi yang menyesuaikan dengan keadaan tempat barunya. Hal inilah yang sedang dialami Informan 6, yaitu masih mencoba menyesuaikan diri dan cenderung menoleransi budaya-budaya baru yang sedang dihadapinya.

\section{Pernikahan sebagai Cita-cita dalam Hubungan Romantis}

Negara memandang pernikahan sebagai suatu ikatan lahir batin antara seorang pria dengan seorang perempuan sebagai suami istri dengan tujuan membentuk keluarga (rumah tangga) yang bahagia dan kekal berdasarkan Ketuhanan Yang Maha Esa (Wibisana, 2016). Dalam agama islam, pernikahan termasuk dalam sunnah, yakni ibadah yang dianjurkan untuk mencapai kebahagiaan dunia dan akhirat. Oleh sebab itu, pernikahan acap kali dianggap sebagai tujuan akhir atau cita-cita dari hubungan romantis. Gambar 4 merupakan contoh postingan pernikahan selebgram.

\section{hamidahrachmayanti}

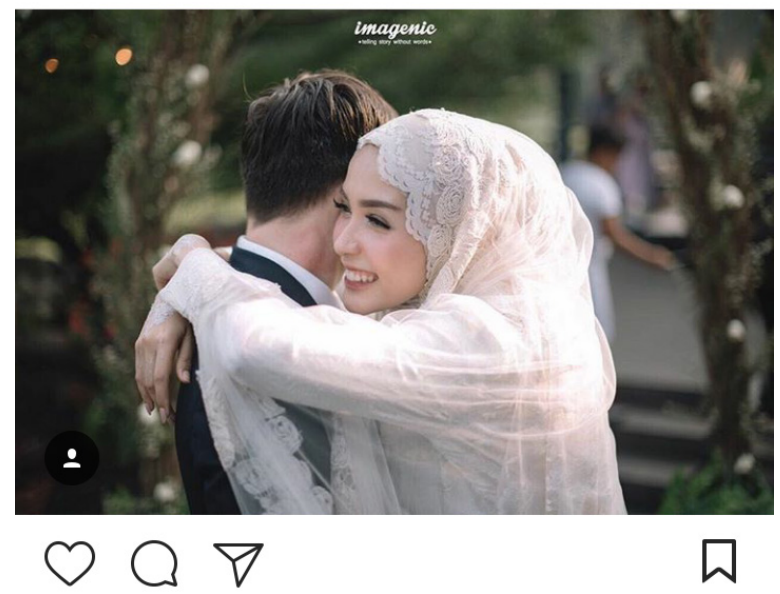

Liked by ngka_, serawulandari and 51,754 others hamidahrachmayanti I never felt like this before. He makes me feel so special, he treats me like a princess. I love you, I really do.

Gambar 4. Pernikahan sebagai cita-cita dalam hubungan romantis
Postingan hubungan romantis pada pasangan menikah diterima dan disetujui oleh para informan. Mereka melihat pernikahan sebagai institusi yang melegalkan segala aktivitas hubungan romantis, mulai dari postingan yang menunjukkan kedekatan, ketergantungan, komitmen hingga kemesraan merupakan hal yang wajar untuk disebarkan di instagram.

"Postingan yang nunjukkin kebahagiaan itu ada di pasangan yang udah menikah, apalagi kalau postingannya mengandung kesan islami, itu baru relationship goal yang beneran," (Informan 3, 28 tahun, Ibu Rumah Tangga).

Relationship goal merupakan ungkapan yang populer di instagram. Ungkapan tersebut bermakna hubungan cinta yang dianggap ideal dan diinginkan oleh para pengguna. Tanggapan para pengguna tersebut biasanya tertera pada kolom komentar postingan-postingan hubungan romantis yang menunjukkan kebahagiaan. Bagi Informan 3 yang telah berumah tangga selama satu tahun, konsep pernikahan yang ideal tergambar dari postingan yang menunjukkan rumah tangga islami, seperti: menunaikan ibadah bersama-sama, suami sebagai imam keluarga dan anak-anak yang soleh. Hal serupa diungkapkan oleh Informan 4 melalui pernyataan sebagai berikut:

"Mungkin di otak kita udah terkonstruksi kalau orang yang udah nikah itu ya berarti komit dengan hubungannya jadi sah-sah ajalah posting apapun. Beda dengan (pasangan) yang masih pacaran, belum saatnya posting tentang komitmen hubungannya, emang yakin bakal dinikahin?" (Informan 4, 28 tahun, karyawan swasta).

Stenberg mendefinisikan komitmen sebagai usaha-usaha yang dilakukan untuk mempertahankan hubungan (Graham, 2011). Jika gairah kemesraan cenderung muncul pada awal terbentuknya hubungan romantis, keintiman dan komitmen tumbuh dan berkembang seiring dengan berjalannya relasi tersebut. Dalam hukum islam, komitmen dalam pernikahan 
diwujudkan dengan adanya akad, yaitu perjanjian yang berlangsung antara dua pihak yang melangsungkan pernikahan dalam bentu ijab qabul (Wibisana, 2016). Selain ijab qabul, syarat lain dalam pelaksanaan akad adalah adanya wali, saksi dan mahar.

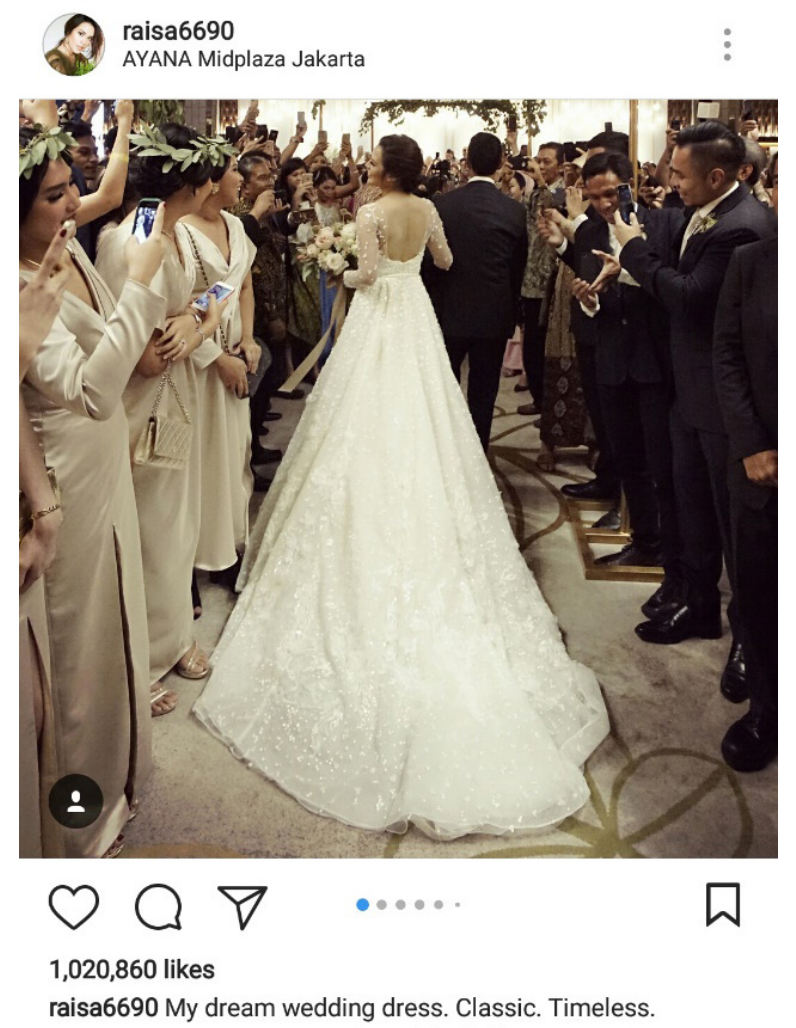

Gambar 5. Pernikahan instagramable sebagai standarisasi baru konsep pernikahan

Selain sebagai wujud dari komitmen pada hubungan romantis, postinganpostingan di instagram juga membentuk standar baru terhadap perayaan pernikahan. Saat ini, perayaan pernikahan dibuat sedemikian rupa agar dapat layak diperlihatkan di dunia maya. Tampilan instagram memungkinkan pengguna-nya untuk membuat cerita mengenai pernikahan yang instagram-able.

"Waktu Raisa ngumumin akan menikah, instagram penuh dengan foto-foto perayaan dari mulai lamaran, pengajian, akad sampai resepsi pernikahan. Bagus banget konsep dan dekor-nya. Aku sih pengen yaa, siapa sih yang gak mau pernikahannya dirayain seindah dan semeriah itu?" (Informan 5, 19 tahun, mahasiswa).

Informan 5 menilai pernikahan sebagai tahapan baru pada kehidupan sehingga wajar jika dirayakan secara meriah. Terkait tren postingan pernikahan yang instagram-able (lihat contoh pada gambar 5), menurutnya, hal tersebut adalah hal yang wajar karena instagram telah menjadi bagian dari gaya hidup pengguna-nya. Instagram mampu membentuk realitas yang di dalamnya terdapat interaksi dan hubungan sosial sebagaimana terdapat di dunia nyata. Realitas tersebut membentuk nilai-nilai, memiliki pola, terstruktur dan memunculkan inovasi-inovaasi baru sebagai jawaban dari evolusi yang terjadi di dunia virtual (Nasrullah, 2016). Pernikahan yang instagram-able adalah salah satu contoh bagaimana instagram memunculkan inovasi baru, yaitu standarisasi baru mengenai suatu konsep bagi penggunanya.

\section{Kemesraan pada Hubungan Romantis yang Disebarkan di Instagram}

Kemesraan atau gairah yang diwujudkan dengan kontak fisik merupakan salah satu bentuk ekspresi cinta yang dikemukakan oleh Chapman (Eickstein dan Morristen, 1999). Kontak fisik tersebut meliputi berpegangan tangan, berciuman hingga melakukan hubungan intim.

Sebagai negara yang mengedepankan kesantunan, ekspresi kemesraan yang ditunjukkan di ruang publik merupakan hal yang dianggap tidak pantas di Indonesia. Namun, hal yang berbeda terlihat pada postingan-postingan hubungan romantis di instagram. Semakin terbukanya informasi yang dahulu dianggap tabu tersebut, setiap individu bebas untuk mengomunikasikan apapun tanpa dikekang oleh batasan nilai dan norma-norma konvensional (Aryani, 2008). Gambar 6 merupakan contoh postingan yang menunjukkan kemesraan.

"Hubungan yang manis gak perlu ditunjukkan dengan posting foto mesra. Silakan foto seperti itu, tapi dipajang di rumah aja jangan di media sosial." (Informan 4, 27 tahun, karyawan swasta). 
rachelvennya

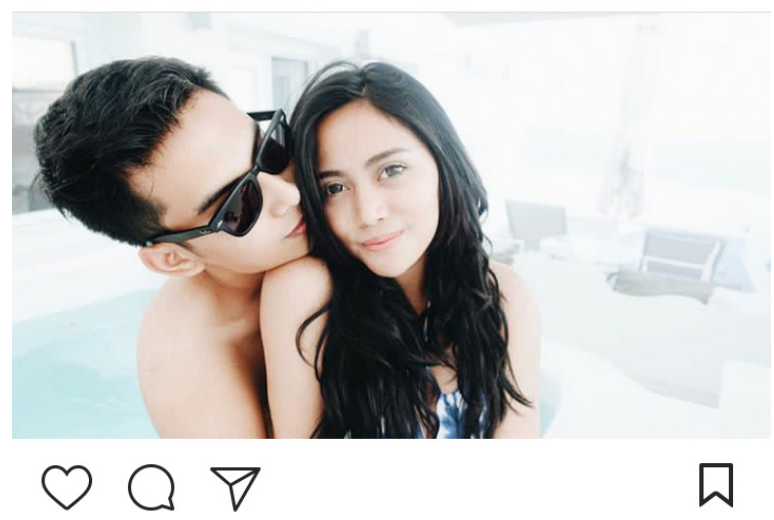

Liked by dapurgladies, adjengkireina and 180,941 others

View all 539 comments

\section{Gambar 6. Postingan kemesraan}

Informan 4 memandang selebgram sebagai public figure seharusnya paham apabila dirinya memiliki daya untuk memengaruhi followers-nya. Menurutnya, apa yang menjadi tidak pantas jika disebarkan secara terus menerus akan mengubah sifatnya menjadi benar dan diterima sebagai nilai baru oleh para penggemarnya. Pada interaksi sehari-hari, keyakinan terhadap norma dibentuk oleh orang-orang terdekat, seperti orangtua, pasangan, teman juga figur terkenal (Liendenberg, Joly dan Stapel, 2011). Selebgram merupakan figur yang dapat memberi pengaruh pada keyakinan seseorang terhadap norma. Penggemar, terlebih yang masih masuk usia muda, menganggap idolanya sebagai gambaran konsep diri yang ideal (Caughey dalam Chan, 2011), sehingga mereka mengelola dirinya serupa dengan idolanya tersebut (Chan, 2011).Penelitian yang dilakukan oleh Azimar mengenai perilaku seksual pranikah mendapatkan hasil bahwa ada pengaruh yang siginifikan antara akses media dengan aktivitas seksual sebelum menikah (Azimar, 2013). Pendidikan seks, baik dalam lingkup keluarga maupun sekolah, masih tergolong minim di Indonesia. Oleh sebab itu, media menjadi sarana pembelajaran yang mudah bagi individu terkait aktivitas seksual.

Agama dan adat budaya merupakan alasan para informan mengapa kemesraan dianggap tidak patut untuk disebarkan di instagram. Norma-norma dan aturan agama menjadi pagar yang membatasi perilaku tersebut untuk tidak diperlihatkan di ruang publik. Di samping itu, seperti halnya agama dan adat budaya, pengalaman pribadi juga turut memengaruhi sikap informan terhadap diskursus hubungan romantis di instagram. Hubungan romantis merupakan relasi yang umum dialami oleh individu, sehingga dalam menjawab pertanyaan-pertanyaan pada penelitian ini, para informan merefleksikan apa yang mereka lihat di media dengan apa yang terjadi sesungguhnya pada dirinya. Hal ini dapat dilihat dari keterangan Informan 3, sebagai berikut:

"...yang kulihat di instagram justru (pasangan) yang pacaran yang kelihatan lebay, mungkin pengen dilihat hubungannya so sweet gitu kali yaa. Aku tho udah nikah, rumah tangga gak se-sweet itu," (Informan 3, 28 tahun, Ibu Rumah Tangga).

Pendapat lain diungkapkan oleh Informan 2. la berpendapat bahwa kemesraan yang ditampilkan lewat kontak fisik yang ia lihat di instagram masih dalam batas kewajaran. Menurutnya, ada pihak berwenang yang mengawasi dan berhak menegur apabila postingan-postingan tersebut dianggap salah.

"Postingan kontak fisik sejauh ini masih wajar-wajar aja. Kalo gak wajar dan berlebihan kan pasti udah diciduk ama Cyber Crime kaya yang kejadian ama siapa itu dulu? Setelah kejadian itu gak ada lagi kan yang diciduk berarti masih oke," (Informan 2, 24 tahun, Karyawan Swasta).

Pernyataan Informan 2 terkait dengan peristiwa yang terjadi pada Oktober 2016 di mana dua akun selebgram dilaporkan ke Komisi Perlindungan Anak Indonesia (KPAl) karena dituduh menyebarkan postingan yang bertentangan dengan norma sosial dan pornoaksi. Berkaitan dengan hal tersebut, KPAI bersama Kementerian Komunikasi dan Informatika dan Cyber Crime, unit 
khusus Kepolisian Republik Indonesia yang menangani pelanggaran di dunia siber, mengadakan pertemuan dengan kedua selebgram untuk membahas permasalahan yang sedang banyak diperbincangkan masyarakat. Hal ini yang menjadi perhatian Informan 2 dalam menyikapi postingan kemesraan yang dilihatnya di instagram. Ketika pihak berwenang belum bergerak untuk menertibkan postingan-postingan tersebut, artinya masih berada di dalam batas norma dan wajar untuk dikonsumsi khalayak.

Terkait norma, ada tiga komponen yang terkandung di dalamnya, antara lain nilai, penghargaan dan sanksi (Ruman, 2009). Nilai mengandung ide-ide yang penting bagi masyarakat. Sementara itu, penghargaan diberikan atas perilaku yang sesuai dengan norma, sedangkan sanksi merupakan hukuman untuk segala perilaku yang dianggap bertentangan dengan norma yang disepakati bersama. Norma yang melahirkan aturan-aturan dalam berperilaku dikenal sebagai hukum. Shaefer mengemukakan bahwa hukum harus dipahamai sebagai instrumen kontrol sosial pemerintah melalui agen-agen yang secara spesifik terlatih (Ruman, 2009). Dalam tatanan sosial, hukum dibutuhkan untuk menjalankan kontrol sosial.

Kepolisian Republik Indonesia (POLRI) merupakan pihak yang berwenang untuk menegakkan hukum di masyarakat. Seiring dengan perkembangan teknologi komunikasi, POLRI membentuk unit khusus yang mengurusi permasalahan di dunia siber, yaitu Unit Cyber Crime. Di awal terbentuknya, kejahatan di dunia siber hanya terfokus pada sistem operasi dalam jaringan internet. Namun, saat ini konsep tersebut meluas hingga ke ranah pornografi. Postingan media sosial yang menunjukkan kemesraan seringkali disebutkan termasuk pada pelanggaran ini sehingga perlu adanya campur tangan lembaga formal untuk menyelesaikannya.

\section{E. KESIMPULAN}

Peneliti mendapatkan hasil penelitian yang dibagi ke dalam tiga kategori berdasarkan tiga posisi audiens yang dikemukakan oleh Stuart Hall. Pertama, agama, adat budaya dan pengalaman membentuk batasan pada hubungan romantis yang disebarkan di instagram. Kedua, pernikahan sebagai cita-cita hubungan romantis. Ketiga, kemesraan yang disebarkan di instagram.

Para informan menegosiasi postingan hubungan romantis yang memenuhi batasan-batasan yang terbentuk dari norma agama, adat budaya dan pengalaman pribadi mereka. Postingan tersebut berupa postingan yang menunjukkan kedekatan dan ketergantungan selebgram dengan pasangannya yang diperlihatkan secara tidak berlebihan dan terus menerus. Sementara itu, pada informan yang berasal dari pedesaan dan baru memasuki kehidupan perkotaan, postingan kontak fisik dinegosiasi karena pertimbangan adanya perbedaan adat budaya yang dianut oleh selebgram yang hidup di kota besar dengan dirinya yang berada di kota kecil. Sementara itu, para informan menyetujui semua postingan hubungan romantis yang diunggah oleh selebgram yang telah menikah.

Pernikahan dipandang sebagai tujuan akhir sekaligus lembaga yang melegalkan hubungan romantis sehingga apapun bentuk ekspresinya dipandang wajar oleh para informan. Terkait tren pernikahan yang instagram-able, informan yang berusia paling muda menjadikan tren tersebut sebagai konsep yang ideal. Realitas yang dibentuk di instagram pada akhirnya membentuk standarisasi baru terhadap konsep yang diterapkan di dunia nyata. Postingan yang menunjukkan kemesraan ditolak oleh sebagian besar informan. Kontak fisik yang diperlihatkan oleh pasangan pacaran dianggap menyalahi norma dan aturan agama. Berkebalikan dengan pendapat mayoritas, informan yang tinggal di Jakarta dan bergaul di lingkungan yang terbuka berpendapat jika 
kemesraan yang diperlihatkan di instagram tergolong wajar. Jika postingan-postingan tersebut salah, seharusnya sudah mendapat peringatan dari pihak berwenang yang mengawasi aktivitas di dunia siber.

Keterbukaan hubungan romantis di instagram diresepsi berbeda-beda oleh para informan. Perbedaan budaya, usia dan gaya hidup menjadi latar belakang mengapa konsep tersebut disikapi secara beragam. Selain itu, instagram terbukti telah menciptakan konsep baru yang dipercaya dan berimplikasi pada realitas di dunia nyata para penggunanya. Pada penelitian lanjut, informan dapat diperluas ke gender lain dan menggunakan media sosial selain instagram. Penelitian lanjutan juga dapat diarahkan untuk melihat secara lebih detil mengenai konsep atau nilai baru yang diciptakan di media sosial dan implementasinya di realitas di dunia nyata.

\section{DAFTAR PUSTAKA}

Al-kandari, A., Melkote, S. R., \& Sharif, A. (2016). Needs and Motives of Instagram Users that Predict Self-disclosure Use : A Case Study of Young Adults in Kuwait. https://doi. org/10.1177/0973258616644808

Aran-ramspott, S., \& Medina-bravo, P. (2015). Exploring the Spanish youth audience's interpretation of loving relationships. https://doi.org/10.1177/0163443715577243

Aryani, Kandi. (2008). Penerimaan Remaja terhadap Wacana Pornografi Dalam Situs-situs Seks di Media Online. Jurnal Penelitian Dinamika Sosial Vol.7/ No. 2.

Asmara, Lita Rengga dan Kusuma, Rinasari (2016). Pria Barat Ideal Menurut Pandangan Khalayak Indonesia (Studi Pandangan Khalayak Indonesia Tentang Sosok Pria Barat Ideal Melalui Karakter Fiksi Dalam Film Drama Romantis Hollywood). The 4th University Research Coloquium 2016. Page 132-147.

Asosiasi Penyelenggara Jasa Internet Indonesia (2016). Infografis Penetrasi \& Perilaku Pengguna Internet Indonesia Survei 2016. Polling Indonesia.

Boyd, Danah M. and Ellison, Nicole B. (2008). Social Network Sites: Definition, History and Scholarship. 210-229.

Budge, K. (2017). Objects in Focus: Museum Visitors and Instagram. Curator: The Museum Journal, 60(1), 67-85. https://doi.org/10.1111/cura.12183

Chan, K. (2011). What preteen girls learn about gender roles from celebrities. Paper published by, 1(2), 79-87. Retrieved from http://www.coms.hkbu.edu.hk/karachan/ file/JMC_celebrities_Nov_2011.pdf

During, Simon (1999). The Cultural Studies, Second Edition. New York: Routledge.

Eckstein, D., \& Morrison, J. (1999). Exploring Different Expressions of Love. The Family Journal, 7(1), 75-76. https://doi.org/10.1177/1066480799071014

Graham, J. M. (2011). Measuring love in romantic relationships : A meta-analysis, 28(6), 748771. https://doi.org/10.1177/0265407510389126

Kriyantono, Rachmat (2012). Teknik Praktis Riset Komunikasi: Disertai Contoh Praktis Riset Media, Public Relations, Advertising, Komunikasi Organisasi, Komunikasi Pemasaran. Jakarta: Kencana Prenada Media Group.

Kusuma, R. S. (2016). Penggunaan Internet Oleh Dosen Berdasar Gender. Komuniti, Vol. VIII, No. 1. 53-63. 
Lindenberg, S., Joly, J. F. and Stapel, D. A. (2011). The Norm-Activating Power of Celebrity: The Dynamics of Success and Influence. SPQ Retraction Statement, 75(March 2011), 98-120. https://doi.org/10.1177/0190272512471170

Littlejohn, Stephen W. and Foss, Karen A. (2009). Theories of Human Communication, 9th ed. terj. Mohammad Yusuf Hamdan. Jakarta: Salemba Humanika.

Littlejohn, Stephen W., Karen A. Foss, E. (2009). Encyclopedia of Communication Theory. California: Sage Publications, Inc.

Masur, P. K., \& Scharkow, M. (2016). Disclosure Management on Social Network Sites: Individual Privacy Perceptions and User-Directed Privacy Strategies. https://doi. org/10.1177/2056305116634368

Mathieu, D. (2015). The Continued Relevance of Reception Analysis in the Age of Social Media. Tripodos, (36), 13-34.

McQuail, Denis (2011). Teori Komunikasi Massa McQuail v.2. Diterjemahkan oleh Izzati dan Putri Iva. Jakarta: Salemba Humanika.

Miller, Rowland S., (2012). Intimate Relationships. Sixth Edition. Sam Houston State University.

Nanda, Lidya (2012). Interpretasi Khalayak Terhadap Retorika Politik Dalam Televisi (Studi Kasus "Apa Kabar Indonesia" TV One. Tesis pada program Magister. Universitas Indonesia.

Nasrullah, Rulli, Nurbaya, Nunik Siti (2015). Media Sosial: Perspektif Komunikasi, Budaya dan Sosioteknologi. Bandung: Simbiosa Rekatama Media.

Omarzu, J. (2000). A Disclosure Decision Model: Determining How and When Individuals Will Self-Disclose. Personality and Social Psychology Review, 4(2), 174-185. https://doi. org/10.1207/S15327957PSPR0402_05

Picone, I. (2017). Conceptualizing media users across media: The case for media user/use as analytical concepts. Convergence, 23(4), 378-390. https://doi. org/10.1177/1354856517700380

Pratama, Afiyanta Rizal (2011). Sosialisasi Nilai Dan Norma Agama Islam Pada Anak Usia Dini Oleh Guru Dan Orangtua Di PAUD Purnama Gatak Kelurahan Kedungan Kecamatan Pedan Kabupaten Klaten Tahun Ajaran 2009-2010. Skripsi pada program Sarjana Ilmu Sosiologi. Universitas Sebelas Maret.

Rachman, R. A. (2012). Pemaknaan Iklan Layanan Masyarakat Lingkungan Hidup ( Analisis Pemaknaan Mahasiswa Kehutanan Terhadap Iklan " HUTAN: Sumber Kehidupan, Keanekaragaman Hayati "). Universitas Indonesia

Rains, S. A., Brunner, S. R., \& Oman, K. (2016). Self-disclosure and new communication technologies: The implications of receiving superficial self-disclosures from friends, 33(1), 42-61. https://doi.org/10.1177/0265407514562561

Ratna, Nyoman Kutha (2010). Metodologi Penelitian Kajian Budaya Dan Ilmu-ilmu Sosial Humaniora Pada Umumnya. Yogyakarta: Pustaka Pelajar.

Ruben, Brent, D., dan Stewart, Lea P. (2013). Komunikasi Dan Perilaku Manusia. Jakarta: RajaGrafindo Persada.

Ruman, Yustinus Suhardi. (2009). Keteraturan Sosial, Norma dan Hukum: Sebuah Penjelasan Sosiologis. Jurnal Hukum Prioris. Volume 2. Nomor 2.

Sa'adatina (2017). Penggunaan Media Sosial Dalam Dinamika Hubungan Pacaran: Studi Terhadap Penggunaan Instagram Pada Pasangan Berpacaran. Universitas Diponegoro. 
Shaw, A. (2017). Encoding and decoding affordances: Stuart Hall and interactive media technologies. Media, Culture \& Society, 39(4), 592-602. https://doi. org/10.1177/0163443717692741

Suryani, Fitria Listie dan Suwarti, Ch. Heni Dwi (2014). Instagram Dan Fashion Remaja (Studi Kasus Peran Media Sosial Instagram terhadap Tren Fashion dalam Akun @ootindo Tahun 2014). Skripsi pada program Sarjana Ilmu Komunikasi. Universitas Sebelas Maret.

Syah, Hidayat (2013). Urbanisasi dan Modernisasi (Studi Tentang Perubahan Sistem Nilai Budaya Masyarakat Urban di Pangkalan Kerinci Kabupaten Pelalawan). Toleransi, Vol. 5 No. 1 Januari-Juni 2013.

Tsay-vogel, M., Shanahan, J., \& Signorielli, N. (2016). Social media cultivating perceptions of privacy: A 5-year analysis of privacy attitudes and self-disclosure behaviors among Facebook users. https://doi.org/10.1177/1461444816660731

van Dijck, J. (2008). Digital photography: communication, identity, memory. Visual Communication, 7(1), 57-76. https://doi.org/10.1177/1470357207084865

West, Richard and Turner, Lynn H. (2010). Introducing Communication Theory (Analysis And Application). New York: McGraw-Hill.

Wibisana, Wahyu. (2016). Pernikahan Dalam Islam. Jurnal Pendidikan Agama Islam-Ta'lim. Vol. 14 No.2-2016 